\title{
Mathematical Analysis for the Optimization of Wastewater Treatment Systems in Facultative Pond Indicator Organic Matter
}

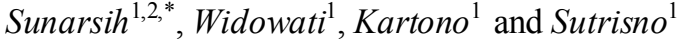 \\ ${ }^{1}$ Department of Mathematics, Faculty of Science and Mathematics, Diponegoro University, Semarang - Indonesia \\ ${ }^{2}$ Doctoral Program of Environmental Science, School of Postgraduate Studies, Diponegoro University, Semarang-Indonesia
}

\begin{abstract}
Stabilization ponds are easy to operate and their maintenance is simple. Treatment is carried out naturally and they are recommended in developing countries. The main disadvantage of these systems is large land area they occupy. The aim of this study was to perform an optimization of the wastewater treatment systems in a facultative pond, considering a mathematical analysis of the methodology to determine the model constrains organic matter. Matlab optimization toolbox was used for non linear programming. A facultative pond with the method was designed and then the optimization system was applied. The analyse meet the treated water quality requirements for the discharge to the water bodies. The results show a reduction of hydraulic retention time by 4.83 days, and the efficiency of of wastewater treatment of 84.16 percent.
\end{abstract}

\section{Introduction}

In today's life, settlements are more centered on a residential area. This poses a new problem especially in sewerage systems. The precise way of disposing of wastewater that is flowing into the river was considered successful. At first, it was not cause problems because the amount of liquid waste is small compared to the river flow. But with increasing waste disposal, the pollution is increasing to pollute the environment. Centralized settlements make the collection of domestic waste water in sewerage very high. If the waste is throw without first processing, it can reduce the quality of river water. To solve the problem, wastewater needs the processing process first before it is streamed into the water system. One of the processes is using a centralized Wastewater Treatment Plant unit (WWTP).

Waste Stabilization Ponds are used to improve the quality of waste water by relying on natural processes that treat wastewater by utilizing the presence of bacteria, algae and zooplankton to reduce the organic pollutants contained in wastewater [1-4].

Commonly used waste water disposal systems are waste water coming from toilets flowed into septic tanks and runoff from septic tanks impregnated into the soil or discharged into waterways, whereas non-toilets that come from bathing, washing and kitchen waste is discharged directly into waterways.

Improper waste water management causes problems, for example, health risks due to contamination by pathogens, odors, and loss of biodiversity. The purpose of a pond system is to keep and treat wastewater with the specified retention time [5-6]. Stabilization ponds may function independently or in combination with other processing systems. Stabilization ponds are usually designed with a system which consist of 2 types of pond that is facultative and maturation, because it is easy to operate and easy to maintain [7]. The purpose of this research is to know the optimum waste load and the level of degradation of organic matter. Mathematical analysis is used by applying linear program, so the results of wastewater treatment fulfill the quality standard.

\section{Materials and Methods}

\subsection{Linear Program Application}

Linear program is applied to wastewater treatment system at Wastewater Treatment Plant (WWTP), Sewon, Bantul, Yogyakarta. Optimization is reviewed from the treated waste load by analyzing the efficiency of wastewater treatment so as to meet the quality standard.

The formulation of the model begins by determining the objective function to maximize wastewater treatment in facultative stabilization ponds. To determine the constraint function, the model is limited by the concentration of Biochemical Oxygen Demand (BOD) with the efficiency of wastewater treatment in each pond to meet the quality standard. The wastewater treatment system scheme in the stabilization pond for model formulation assuming no consider to the maturation pond can be seen in Figure 1.

\footnotetext{
Corresponding author: narsih pdil@yahoo.com
} 


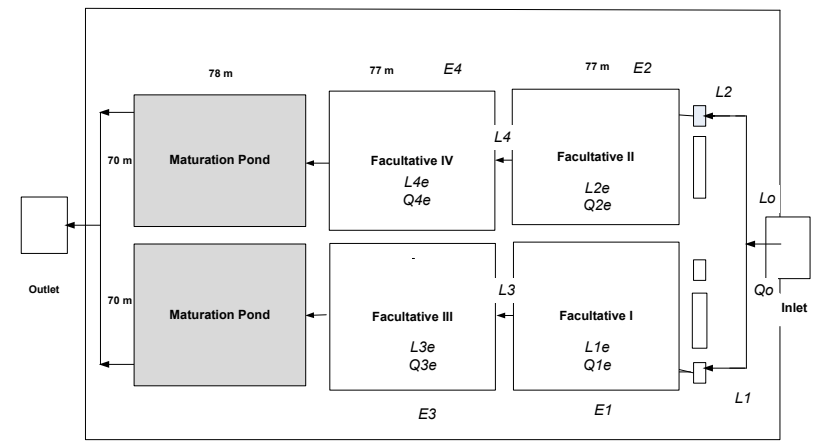

Fig. 1. Wastewater Treatment Scheme in Facultative Pond

with:

$L_{0} \quad$ : The initial waste load that goes into the inlet (kg/day)

$Q_{0} \quad:$ Debit of waste water in inlet $\left(\mathrm{m}^{3} /\right.$ day)

$Q_{i e} \quad:$ Debit of waste water in pond $i\left(\mathrm{~m}^{3} /\right.$ day)

$L_{i} \quad$ : Wastewater load before entering pond $i(\mathrm{~kg} / \mathrm{day})$

$L_{\text {ie }} \quad$ : The amount of wastewater treatment in pond $\mathrm{i}$ (kg/day)

$C_{i} \quad$ : Concentration of BOD of pond i $(\mathrm{mg} / \mathrm{L})$

$L \quad:$ Wastewater load $(\mathrm{kg} /$ day)

$E_{i} \quad$ : Efficiency of wastewater treatment in pond $\mathrm{i}$

$B M \quad$ : Wastewater quality standards

From Figure 1 can be formulated into a model with a linear program on a water treatment system in WWTP Sewon, Bantul as follows.

Objective Function:

Maximize $Z=L_{1 e}+L_{2 e}+L_{3 e}+L_{4}$

Constraint Function:

- $E_{1} C_{1} \leq B M$

- $E_{2} C_{2} \leq B M$

$-\quad E_{3} C_{3} \leq B M$

- $E_{4} C_{4} \leq B M$

$-\quad L_{1 e} \leq L_{1}$

$-\quad L_{2 e} \leq L_{2}$

$-\quad L_{3 e} \leq L_{3}$

$-\quad L_{4 e} \leq L_{4}$

The amount of incoming waste load on the wastewater treatment system in the facultative stabilization pond is the debit of waste water along with the organic material Biochemical Oxygen Demand (BOD) formulated as $L_{i e}=\frac{\left(Q_{i e} \cdot C_{i}\right)}{1000}$ and $C_{i}=\frac{\left(1000 L_{i}\right)}{Q_{i e}}$, the linear program model becomes as follows.

Objective Function:

Maximize $Z=L_{1 e}+L_{2 e}+L_{3 e}+L_{4 e}$

Constraint Function:

$-\quad E_{1} \frac{\left(1000 L_{1}\right)}{Q_{1 e}} \leq B M$

$$
\begin{array}{ll}
- & E_{2} e \frac{\left(1000 L_{2}\right)}{Q_{2 e}} \leq B M \\
- & E_{3} \frac{\left(1000 L_{3}\right)}{Q_{3 e}} \leq B M \\
- & E_{4} \frac{\left(1000 L_{4}\right)}{Q_{4 e}} \leq B M \\
- & L_{1 e} \leq L_{1} \\
- & L_{3 e} \leq L_{1}-L_{1 e} \\
- & L_{2 e} \leq L_{2} \\
- & L_{4 e} \leq L_{2}-L_{2 e}
\end{array}
$$

To solve the equation, we assume the model with the facultative stabilization pond conditions as follows.

1. The amount of waste water debit in inlet $\mathrm{Q}_{0}$ with period of time for 1 year (January - December 2016 ) is $11,238.38 \mathrm{~m}^{3} /$ day.

2. The waste retention time in the facultative pond is an average of 4.83 days and the retention time of waste in each month as in Table 1.

Table 1. Waste Retention Time the Period from January to December 2016

\begin{tabular}{cccc}
\hline No & Month & $\begin{array}{c}\text { Debit } \\
\left(\mathbf{m}^{\mathbf{3}} / \mathbf{d a y}\right)\end{array}$ & $\begin{array}{c}\text { Retention Time } \\
\text { (day) }\end{array}$ \\
\hline 1 & January & $10.997,22$ & 3,97 \\
2 & February & $11.853,80$ & 3,68 \\
3 & March & $15.951,28$ & 3,94 \\
4 & April & $13.937,84$ & 4,13 \\
5 & May & $13.187,30$ & 4,31 \\
6 & June & $12.071,40$ & 4,82 \\
7 & July & $10.616,44$ & 4,11 \\
8 & August & $8.243,10$ & 5,6 \\
9 & September & $7.534,32$ & 5,8 \\
10 & October & $8.044,08$ & 5,43 \\
11 & November & $10.378,02$ & 6,3 \\
12 & December & $12.045,77$ & 5,83 \\
\hline \multicolumn{2}{c}{ Average } & $11.238,38$ & 4,83 \\
\hline
\end{tabular}

3. The waste load on the Facultative I $\left(L_{1}\right)$ and Facultative II Pond $\left(L_{2}\right)$ are half of the inlet initial load $\left(L_{0}\right)$. The organic waste load is known from the number of residents connected with the Sewon WWTP system which includes the number of households as many as 54,440 people, social places (worship places and others) as many as 8,550 people, commercial places as many as 49,350 people and hotels as many as 7,650 people, so wastewater comes from 119,990 people. The standard clean water requirement in developing countries is $120 \mathrm{~L} /$ person/day and each person produces 40 grams of BOD per day. So the BOD concentration of Sewon is equal to $0.41667 \mathrm{gr} / \mathrm{L}$ or $416,67 \mathrm{mg} / \mathrm{L}$ and total BOD load or inlet load $\left(L_{0}\right)$ is $119,990 \mathrm{x} 40 \mathrm{gr} /$ person/day which is $4,799,600$ gr/day Or 4,799.6 kg/day. Thus the load of BOD $\left(L_{1}\right)$ and $\left(L_{2}\right)$ is $2,399.8 \mathrm{~kg} /$ day.

4. The coefficient of degradation of BOD $(k)$ for the effective volume of $86.240 \mathrm{~m}^{3}$ in 1 year is 1.1 , with $C_{\text {in }}$ is the rate of change of BOD concentration at 
the inlet and $C_{e f}$ is the rate of change of BOD at the outlet.

Thus, the formulation of the level of degradation of organic material which capable doing in the facultative pond system is as follows.

with:

$$
E=\frac{k \cdot t}{1+k \cdot t}
$$

$k \quad$ : Rate of degradation BOD

$t \quad$ : Waste retention time (days)

From the calculation result obtained that effectivity of wastewater treatment system in facultative pond able to degrade waste equal to $84,16 \%$.

\section{Results and Discussions}

The system of linear program equations is done by simplifying the equation, i.e. by entering the value of known variables. Known variables are debit of waste water in each pond $\left(Q_{i k}\right)$, waste load in each pond $\left(L_{i k}\right)$, efficiency of pond $\left(E_{i}\right)$ and predetermined quality standard $(B M)$. The quality standards of waste water based on the Decision Letter of the Governor of Yogyakarta Special Region No. 214/KPTS/1991 on the domestic waste water quality standard is $50 \mathrm{mg} / \mathrm{L}$. By entering these values of variables, so the objective function of the constraint function is obtained as follows.

\section{Objective Function:}

Maximize $Z=L_{1 e}+L_{2 e}+L_{3 e}+L_{4 e}$

Constraint Function:

$$
\begin{array}{ll}
- & 0.84 \times \frac{\left(1000 L_{1}\right)}{13,475} \leq 50 \\
- & 0.84 \times \frac{\left(1000 L_{2}\right)}{13,475} \leq 50 \\
- & 0.84 \times \frac{\left(1000 L_{3}\right)}{13,475} \leq 50 \\
- & 0.84 \times \frac{\left(1000 L_{4}\right)}{13,475} \leq 50 \\
- & L_{1 e} \leq L_{1}
\end{array}
$$

$$
\begin{array}{ll}
- & L_{3 e}+L_{1 e} \leq L_{1} \\
- & L_{2 e} \leq L_{2} \\
- & L_{4 e}+L_{2 e} \leq L_{2}
\end{array}
$$

Equation systems solved by using software POM$\mathrm{QM}$ version 3.0. This software is used to help math calculations by using the simplex method.

To know the suitability of the model with conditions in the field, so the model is verified with observation data in Sewon's IPAL, Bantul. The observational data were organic BOD concentrations in inlets range from $68.3 \mathrm{mg} / \mathrm{L}-177.2 \mathrm{mg} / \mathrm{L}$ and at outlets range from 13 $\mathrm{mg} / \mathrm{L}-18.8 \mathrm{mg} / \mathrm{L}$.

\section{Conclusions}

Wastewater treatment systems in facultative ponds using mathematical analysis (linear program) are able to degrade organic matter. The intended organic matter is BOD with degradation rate of $84.16 \%$ and can meet the domestic waste water quality standard with waste retention time 4.83 days.

\section{References}

1. B. Beran, F. Kargi, Eco. Model. 181, 39-57 (2005)

2. S. Kayombo, T. S. A. Mbwette, A. W. Mayo, J. H. Y. Katima, S. E. Jorgensen, Eco. Eng. 18, 287-291 (2002)

3. L. Puspita, E. Ratnawati, I. Suryadiputra, Lahan Basah Buatan di Indonesia (Wetlands International Indonesia Programme, Ditjen PHKA, Bogor, 2005)

4. Sunarsih, Purwanto, W. S. Budi, J. Urb. And Env. Eng. 7 (2), 293-301 (2013)

5. K. Naddafi, M. S. Hassanvand, E. Dehghanifard, D. F. Razi, S. Mostofi, N. Kasaee, R. Nabizadeh, M. Heidari, Iran. J. Env. Health. Sci. Eng. 6 (1), 41-46 (2009)

6. H. Abbas, R. Nasr, H. Seif, Eco. Eng. 28, 25-34 (2006)

7. A. N. Shilton, D. D. Mara, Wat. Sci. Tech. 51, 103$106(2005)$ 